\title{
THE CHALLENGES OF IMPLEMENTING PEACE EDUCATION PROGRAMS IN MIDDLE EAST ARAB STATES
}

\author{
MAAMOON ABDULSAMAD MOHAMMED \\ Dept. of Peace and Human Rights, University of Duhok, Kurdistan Region-Iraq
}

(Received: April 22, 2018; Accepted for Publication: September 17, 2018)

\begin{abstract}
This paper discusses the challenges and dilemmas faced in establishing peace education programmes in Middle East Arab states, and considers the prospects of finding approaches for overcoming these issues. It discusses the importance of introducing peace education as a means to establishing peace locally and promoting it globally. In particular, resolving contemporary conflicts needs more local involvement not only in finding solutions but also in taking responsibility for their effective implementation, especially so considering the increasing involvement of international - largely Western - organisations as facilitators and supporters of peace education. Furthermore, not only should education be understood as a process that includes decision-making, policies for designing curricula and their contents, and implementation, but a critical approach within education is needed to encourage more fruitful outcomes while solutions need to be broader and more inclusive, incorporating the multi-ethnic structure of the society affected. It considers the importance of religion, emphasising the need to exploit its ability to provide peace-orientated discourses. Lastly, the paper critiques the relationship between Western and Muslim Arab states regarding their approaches to education and knowledge, and considers its implications for peace education and the need to generate local knowledge relevant to peace education that positively reflects Muslim culture.
\end{abstract}

KEYWORDS: Peace education programmes, Teaching, Violent discourses, School challenges.

\section{INTRODUCTION}

ocieties have become more interconnected
and the impact of violence and wars more widespread, therefore, providing a constructive response is the responsibility of all. At the same time, it is becoming increasingly clear that, in general, it is not possible to resolve conflict by official diplomatic means alone. Meanwhile, education for peace is increasing and becoming recognised as one of the main tools of 'second track diplomacy’ (Montville, 1991) and, as such, may be our primary tool to tackle the ongoing crises of violence and rights abuse while enhancing people's peace-orientated values and skills for managing the unknown future in which conflicts might occur. The 2011 UNESCO report investigating the link between education and 
violence on a worldwide basis demonstrates the profound connection between quality of education and inclination towards violence, indicating that improving the quality of education is highly likely to reduce violence and conflict. The contents of curricula, how they are taught and how the education is organized, all have an impact on how prone to violence students might be, and how vulnerable to extremist discourses and indoctrination. Hence, education policies covering issues ranging from the language of instruction to the centralization/decentralization of educational planning all impact on conflict prevention and prospects for lasting peace (UNESCO, 2011: 257).

Furthermore, it is widely accepted among scholars that education plays an important role in fostering ideology, instilling national consciousness, and shaping individual and collective attitudes (Bush and Saltarel1i, 2000; Barat and Duthie, 2015). Thus, educational curricula and textbooks are tools in the transmittance of a society's ideology to new generations (Bar-On and Adwan, 2006). In view of this, peace education seeks to provide knowledge of values and social skills that will increase positive group interactions among vastly different cultures and countries (Gutek, 2006). It has developed as a means to build critical thinking and awareness of human rights, and the goals of Peace Education Programmes (PEPs) seek to address universal problems and to encourage understanding of the universal values of respect for life, freedom, justice, solidarity, tolerance, human rights, equality between women and men, and shared social responsibility, as expressed in the UNESCO Declaration of 1995 . Peace education can be formally integrated as a single subject in school, or it can involve an integrative approach that introduces peace-orientated values throughout a school's curriculum. In peaceful societies and in conflict-affected societies, such projects may take a variety of forms; for example, education for social cohesion (Tawil and Harley, 2004), peacebuilding education (RobertsSchweitzer, 2006), and education for reconciliation (Cole, 2007:13).

Moreover, since terrorism has become globalised and its effects go beyond state boundaries, fostering a context-based approach to peace education is a necessity. While the aims of peace education may be universal, the specific challenges involved in implementing PEPs in Muslim Arab states are two-fold. On the one hand, because PEPs have often been introduced without sufficient respect for local circumstances, they tend to be resented as impositions by Western organisations and governments. And, on the other, war values and oppressive methods of teaching are rigid and deeply rooted in the structure of the majority of Middle East education systems (Roland, 2004). Peace education has developed as a means to build critical thinking and awareness of human rights, and as an education it seeks to restore relationships and transform negative ethnic stereotypes (Roberts-Schweitzer 2006:2). However, it has yet to make a significant impact on education in the Middle East. So, what kinds of issues are challenging the process and how can it be improved?

This paper aims to map out some main factors that need to be considered to support the development of a peace education that is not only 
sensitive to Middle East culture but also strongly influenced by it and so, too, by peaceful Islamic discourse. Although PEPs can be provided through informal workshops for all ages and situations, the paper focuses on formal approaches to introducing PEPs in Middle Eastern schools drawing on literature from many states including Iraq, Iran, Palestine and Egypt.

After giving an overview of the main issues involved in introducing PEPs in the region, this paper considers the specific context, largely based on the work of scholars concerning various Arab states in the Middle East. Considering the influence of religion as central, this section examines how education currently reinforces violent values through curricula contents, delivered knowledge and methodology, as previously demonstrated in Rwanda by Bijlsma (2009). The paper then identifies approaches and types of discourse, including Islamic teachings, which can positively enhance the ability of education to counter the war-orientated discourses highlighted in the previous section and, so, to promote peace in these countries. It follows with a discussion of the implications and challenges of cooperation with international (largely Western) organisations, before presenting a conclusion that asserts the need for combining the two schools of thought and for peace-orientated Islamic discourse to be more influential in contemporary peace education.

\section{PROBLEMATIZING THE PROCESS OF IMPLEMENTING PEPS}

To understand the full implications of introducing PEPs, it is important to consider the process as a whole, including decision-making, policies involved in designing curricula, the preparatory research and the implementation process, as well as curricula contents and teaching methodology. Over recent decades, the process in Middle East Muslim states has generally involved cooperation of INGOs and the government; consequently, it has tended to rely on a top-down process, imposing pre-designed projects that were not specifically developed to the local context. More recently, local NGOs have been involved, introducing a more sensitive awareness of specific local circumstances. However, this paper is concerned primarily with the issues involved in international organisations top down interventions that remain prevalent.

So why have these interventions been largely ineffective in creating sustainable peace? Firstly, it needs to be understood that programmes depending on international support tend to be informed by a liberal approach to development, although many scholars have criticised these as being ineffective or even detrimental and they emphasise the need to reform the liberal stance underpinning these. A study based in fourteen countries explains that "the case studies do suggest that the liberalization process either contributed to a rekindling of violence or helped to recreate the historic sources of violence in many of the countries that have hosted these missions - a conclusion that casts doubt on the reliability of the peace-through-liberalization strategy as it has been practiced to date" (Roland 2004: 155). At the same time, as Galtung (2009: 
511) argues, "[i]f the road to peace passes through conflict resolution then a transnational, transdisciplinary conflictology is a must for peace studies." Clearly, this requires that, to enable positive changes in peacebuilding, the liberalbased strategy informing peace education needs to be updated and programmes undertaken with more sensitivity to the specific context.

Thus, while international help has aided many post-conflict societies in implementing PEPs, such as interventions in Rwanda, Serbia and Bosnia, many of those implemented in Muslim Arab states have failed to take local knowledge into consideration; hence, locally, these are not seen as legitimised and consequently meet resistance or outright rejection (Cole and Barsalou, 2006). To achieve a genuine form of sustainable peace, such programmes need to be based more directly on local perspectives and all stakeholders must be more involved in their process and design. As the traditional Kurdish saying goes: "Only the sick person knows what the pain is".

Further to this, one of the tenets of peace education is that it should take an inclusive approach so all ethnic groups living in a society are represented fairly in the process of education. Thus, to ensure this is fulfilled, it is essential that the specific situations existing in the multi-ethnic societies of the Middle East are well understood, including their long histories of ethnic hatred and the persistent violation of minorities' rights. Empirical studies have demonstrated that exclusion of ethnic groups increases the probability of civil war (Cederman, Gleditsch \& Buhaug, 2013; Cederman, Wimmer \& Min, 2010).

\section{THE CONTEXT OF MIDDLE EAST MUSLIM ARAB STATES}

At the moment, many Muslim states are plagued with intractable conflicts, high rates of human rights violations and disrespect for nonMuslims - or peace is maintained through coercion and violence, making it intrinsically unstable. Maytók (2011) has argued that when human rights are violated in intractable conflicts, violent behaviour among the populace follows. The culture of patriarchy and tribal systems that dominate in Arab countries teach that men and boys are superior to women, and masculinity more powerful than femininity. Accordingly, these cultural beliefs mostly favour violent methods of resolving conflict since peaceful methods, such as reconciliation and forgiveness, are considered tools and symbols of weakness and go contrary to the cultural norms.

Like many people around the world, those in Muslim majority states have lived with overt and hidden discourses of violence and hatred toward the 'other' for a long time and consequently these have become part of life. Violent values, behaviours and attitudes are inherited and passed from generation to generation without counter discourses to challenge them. The situation is referred to as systemic violence, that is, it is imbedded in the political, economic and social forces needed to maintain things so they can carry on as normal (Zizek, 2008). Two areas of life are particularly influential in perpetuating these discourses - religion and education, and these need particular attention. 


\section{THE ROLE OF RELIGION}

Religion is an integral part of Muslim states and as such it is too important to be denied or marginalised; it shapes people's worldviews and is able to mobilise them through influential religious leaders. All knowledge that comes from Islam is accepted by the majority of Muslims without question or criticism. In particular, knowledge about conflict resolution is extracted from Islamic writings; this includes peace-orientated discourses and conflict resolution methods based on the understanding and interpretation of sacred texts, including the Qur'an and the Prophet's Sayings. Such texts and discourses are widely available and families/communities have easy access to them. In Islam, strong emphasis is laid on community as unity rather than on individuality; for instance, human beings are created differently to know one another and live together, they cannot live alone. Human beings are understood to be related through kinships as they have always been. Therefore, the peace of each individual is considered to be intertwined with the peace of the community while, in the West, the accepted understanding of human nature is more concerned with personality and individuality. Through this emphasis on community, Islamic peace discourses can provide alternatives to the radical and violent discourses that are prevalent; and ignoring these alternatives creates barriers to developing an Islamic understating of conflict resolution and transformation (See Abu Namir 2003).

However, religion in the Middle East can be problematic, whether through misunderstandings and \#\#\#incompatibility with Western ideas of conflict resolution, or by neglecting/failing to consider religion as a challenge in establishing peace studies. In particular, Islam intervenes in all aspects of life although many other religions are practiced and, consequently, the values and concepts of all religions involved need to be present in peacebuilding initiatives. Several scholars have identified the role that religion, in general, plays both in resolving and in prolonging ethnic conflict. For example, Fox (1999) shows the influence of religion in creating grievances within different ethnic groups. In addition, when it is used to limit, influence or put constraints on freedom of thoughts for scholars, Islam can inhibit Middle East academic research relating to peace and conflict resolution, and this has made many scholars leave the Middle East for Western states. Indeed, Al-Kubaisi (2012:62) argues that "mental violence" practiced against academic scholars in Iraqi universities has similarities to that promoted by the former Ba'ath regime in demanding that scholars be consistent with its ideology in thought and expression. Hence, in Iraq, despite the political regime change promoting liberal peace in Iraq, and the education reforms that have been made, discrimination is still rife and education is conducted in an atmosphere of violence. This reflects the rigidity of the social structure, where old-fashioned attitudes remain prevalent in education reforms and conflicting issues based on religion have been ignored, along with potentially transformative religious discourses. This is confirmed in several studies of the existence and practice of peace values and conflict resolution in Arabic traditions in state institutions, which find a vacuum. For example, Savigh (2010) found no 
specifically Arabic or Muslim discourses in the conflict resolution policies of Hamas, likewise with Abu Namir's study (2003) of Hizb'Allah in Lebanon.

On the other hand, several studies have demonstrated how religion can be used to resolve conflict (see for example, Johnston and Sampson, 1994; Lederach, 1999) or be a source of conflict resolution (for example, Appleby, 2000, 2006; Hasenclever and Rittberger, 2000). Moreover, lack of religious contribution may hinder the peace process. For example, Gopin (2002) argues that lack of religions' involvement in the Oslo Peace Process was one of the reasons for its failure. However, peace education programmes can be implemented through religion. Indeed, there is widespread agreement among scholars that religious education based on peace values is more effective than non-religious programmes in disseminating values, attitudes and beliefs (see, for example, Abu-Namir, 2001). Moreover, peace education needs to support and develop a moderate understanding of Islam that accepts others as they are and is open to other forms of peacebuilding since marginalising other alternatives by imposing policies and norms have manifestly failed in the Middle East (for more information see Omer, Appleby and Little 2015). To do so, it is important to be aware of the educational context that such programmes are being introduced into, and how religion is incorporated into this.

\section{MAINSTREAM EDUCATION AND WAR TEACHING}

Many Muslim Arab states have experienced long histories of conflict based on inequality, marginalisation and oppression of minority ethnic groups, and schools have played an important role in the internalisation and naturalisation of these values and attitudes. Moreover, in some countries, studies have indicated that war values are strongly represented in the education system and several scholars have demonstrated that violent conflict is a learned practice. For example, Bandura (1973) argues that how children behave in conflict situations is a function of their education, hence, if we change what they learn, their behaviour will follow suit. In the same vein, Eisler (2000) says that violence is not an integral part of human nature but is something that has been exported and institutionalised into our culture through the dominator model, so it is also something that can be removed from society through promoting a partnership model. Similarly, Jabri (1996) argues that violent conflict is not inherit or natural but it is a phenomenon that is produced through social practices over time and within social spaces; social practices become norms and institutionalised through schools and other institutions. For example, in Iraq, Al-Kubaisi argues that, in Iraq,

mental and psychological violence is presented in the university curricula ... the textbooks contents are old fashioned and oriented by religious, sectarian and sub-sectarian biases. And the influence that religion plays in limiting, demanding consistency of thought and expression [is present] to the same degree as the previous Ba'ath government did (Al-Kubaisi, 2012:62-63). 
Conversely, the philosopher, John Dewey (1990) emphasised the need to allow children to participate democratically in their activities to enable them to develop the ability to approach conflict peacefully.

Firer (2002:55) argues that the main reason why peace education is so ineffective is "the continuous war education that youngsters and adults have been receiving since the beginning of mankind". This is especially true in countries that have experienced a long history of violence; their worldviews are shaped by conflict and, thus, their mindsets are difficult to transform through short term programmes. Furthermore, it is difficult for peace education to achieve its aim of enabling different ethnic groups to live in harmony if it is based on rigidly hierarchical power structures. Thus, the social context in most Arab Islamic states makes it difficult to implement PEPs. It has been demonstrated by numerous scholars that, in these states, citizens must unquestioningly accept the norms of the society and obey those in power; people must adapt to the situation - this is in direct contrast with PEP values whereby the situation should be adapted to fit people (for example, see Fandy (2007)). Under these conditions, people are not free thinkers and do not think about the reliability of the knowledge they receive. All is accepted as facts.

In most Muslim countries, Islamic values are incorporated in many subjects in schools such as history education, Arabic studies, and Islamic studies (for example see Doumato and Starrett, 2007). Meanwhile, other religions that exist in their society tend not to be included in the educational structure, content or process; students with other religions are taught as if they are the same. This works to encourage assimilation and integration in the society; however, teaching students as though they were all the same does not create equitable social relations (Bickmore, 2008; Ladson-Billings, 2004; Nieto, 2002). As العيسى (2009:104) argues, in the context of Saudi Arabia, reforms of the education curriculum must include "teaching of human rights", which include respect for and acceptance of diverse opinions (Aarts \& Nonneman, 2005: 79). The lack of representation of non-Muslims in education reinforces the negative societal beliefs that they have toward the 'other'. On the other hand, freedom to partake in critical dialogue fosters critical consciousness (Freire, 1970), provides opportunities for student engagement, activism and inclusion (Apple, 1990; Davies, 2004); it is also an integrative and transformative tenet of peacebuilding education.

To counter the marginalisation of non-Arabs and non-Muslims in Arab Muslim states, education that is based on accepting and respecting diversity is needed. By encouraging students to share their points of difference and diversity, their multiple worldviews become acknowledged (Danesh, 2006; Zembylas and Bekerman, 2013). This involves both what is taught, as represented by the curricula contents, and how it is taught.

\section{CURRICULA CONTENTS}

Al-Barakat and Al-Karaneh (2004:172) state that the textbooks used in Arab states do not nurture critical thinking and teaching is usually based on "reciting information", with teachers 
acting as "sources of information: they present, explain, clarify". This engenders a "passive role in learners" and ignores "the importance of their learning to be active and effective citizens". Valverde (2005:52) further, argues that "the education system of Arab countries is not preparing students to acquire the skills, disposition, the habits of mind associated with competitive economies".

Most Muslim Arab states, whether they have secular or Islamic governments, tend to prioritise the integration of Islamic values into the national curriculum, as in Iraq (Al-Kubaisi, 2012; Mohammed, 2016), Saudi Arabia (العيسى, 2009), and other Islamic studies in the Middle East (Doumato and Starrett, 2007). This can provide a balance to more radical discourses, as Doumato and Starrett (2007:5) note:

an original generic Islam that avoids recognition of sectarian differences and is designed to foster a sense of nationalism, promote the legitimacy of the regime in power, or, in some places, provide a counterweight to an immoderate Islamism being disseminated through public discourse.

However, although the Islamic values used may be laudable in themselves, the effect becomes problematic when they are included while neglecting religious diversity (Leirvik, 2004; Doumato and Starrett, 2007). To live in peaceful coexistence, there has to be no superiority or inferiority of one group over another, otherwise there remain continual undercurrents of resentment that can re-ignite violence. Yet legislation sometimes creates systematic discrimination - for example, the imposing of
Islamic laws on non-Muslim people within society - this is liable to undermine the benefits of the stability provided by promoting the 'legitimacy of the regime in power' because it actually reinforces imbalances.

Moreover, Sameer Ameen (2002) argues that Islamic political movements do not attach very much importance to true religious doctrine and simply select religious discourses that legitimate their political discourses of violence. For this reason, religious discourses can become dangerous and promote conflict. Sheikh Ibn Taymiyya, for example, is quoted by Alkumni (2006:113) as stating, "Everyone who has been informed that they should become Muslims and refused, it is a duty to fight him to avoid being persecuted as all religions must be for Allah"[author's translation]. This is not a discourse that demonstrates integration and peaceful coexistence among different ethnicities in society; it is a discourse for war. In line with this, "there are conditions in the Islamic studies of Saudi Arabia stating that they do not mind Muslims living in Western states for their own benefits, on the condition that Muslims have hatred toward disbelievers in their minds [author's translation]" (Alkumni, 2006:119). As the impact of scholars' interpretation is influential, this is bound to be reflected in textbook contents as these reflect the dominant political discourse (see Mohammed, 2016) for a discussion of this in Iraqi Kurdistan); although some scholars argue that they have not found incitement to violence in the name of religion in Islamic studies textbooks in the Middle East (Doumato and Starrett, 2007), they may not, however, have covered all the 
Islamic textbooks that are studied throughout the Muslim Arab states. Indeed, القفني identifies the incitement to violence in books studied in Alazhar high schools in Egypt. For example, in one of the textbooks he studied, it states:

the killing of disbelievers (Kufar) is obligatory for every sane, able Muslim; ... If they do not become Muslims they have to pay tax and, if they refuse, they fight them, they set up ballista, spoil their plants, trees, and burn them and throw them to the fire [author's translation] (quoted in_2006:83).

Sibra Krader argues that the Arabic states have to reconsider educational issues, perhaps reducing the time on Islamic studies, due to its potential to discourage critical thinking and encourage hatred and racism (cited in Sharef, 2007:12). Moreover, Islamic values are not only presented in Islamic studies but also in other subjects such as Arabic Language, History Education and Patriotic Education (Mohammed, 2016).

For states to build genuinely democratic citizenship, awareness of cultural and social diversity is paramount; yet, many people are not aware of the importance of diversity and think of it as negative. Education has to teach students about different religious traditions rather than focussing on just one - as is often the case both in Middle East and in Western countries (Moore, 2007; Lester, 2011). However, this unilateral perspective is not inherent to Islam. For instance, in his book, Thinking is an Obligation in Islam, (2007) presents evidence from the Quran and the Prophet's Sayings that concerns the importance and the obligation of thinking in Islam and demonstrates that Islam does accept knowledge from other sources for the truth to be revealed. Furthermore, El-Baz (2009:41) cites the great Arab philosopher, Abu Yusef Al- Kindi (805-873), as saying:

We should not shy away from welcoming and acquiring the truth regardless of where it comes from, even if it comes from distant races and nations that are different from us. Nothing is more important than seeking the truth except the truth itself.

Meanwhile, the cultural norms of the society recommend and encourage people to be passive and docile; for instance, current beliefs within the Iraqi Kurdish population, as in many Muslim Arab states, uphold this unquestioning acceptance, proposed by Islamic scholars. Indeed, the great Islamic scholar, Abu Gazali, stated that "the most beloved worshipper to God is the poor man satisfied with what he has". Or "there is no harm in standing quiet in front of the devil all the time". However, the context that Abu Gazali wrote about was very different to present day situations and yet people still generalize these teachings to fit all contexts. The Egyptian philosopher, Zaki Najeeb sums this fatalistic attitude up as: "that which the heaven has ordered, the earth has to obey, the creator has planned and plans, the people have to be satisfied with the division and the fate" (cited in tran. Barakat, 2006:85). The discourse of Sheikh Alkarathawy, one of the great scholars of the Permanent Committee for Islamic Research and Fataawa in Europe, reinforces this attitude:

there is consensus among Islamic scholars that whoever denies one piece of information from religion necessarily, and disbelieves it; he should 
be expelled and the imam must order him to repent and stop doing this, otherwise face apostasy from Islam [author's translation] (quoted in القني,, 2006:83).

Social situations are changing; practices and discourses that were current hundreds of years ago may not be relevant or adaptable to the present day. Moreover, while some religious scripts consider the rules of war and use of violence, there are others that discuss ways to live peacefully. The Mufti of Islam in Egypt, Ali Maki (2013) states that peace is mentioned in the Quran more than 150 places while war is only mentioned in six places. Moreover, differing interpretations of discourses and differing opinions are permissible in Islam. Meanwhile, war-orientated religious discourses in most cases are based on misunderstanding of religions or the monopolization of religious discourses for their own benefit.

Therefore, peace-oriented education is needed to re-educate and open people's minds. شعبان (2011:95) states that the "Quran talked about freedom of religion in more than 100 verses, that indicate tolerance is essential in Islam and these verses demonstrated freedom of religions for nonMuslims, free worshiping, no coercion and respect for other". Belief is mentioned as a matter of personal choice; for example: "There is no compulsion in religion" (Quran 2:256) and "Let him who will believe and let him who will disbelieve" (Quran18:29). Moreover, the role of God's Messenger, Mohammed, was only to deliver the message. As God says in the Quran: "So if they submit, then indeed they follow the right way; and if they turn back, then upon you is only the delivery of the message" (Quran 3:20). However, these verses are not widely cited. Moreover, there are many verses in the Quran that state people must be free to choose the life they lead, thus, imposing religious directives on people of other religions is against the religious principles of Islam - as well as being against the Universal Declaration of Human Rights (UDHR).

\section{THE METHODOLOGY OF TEACHING}

Within most Muslim states, although education is valued highly, the educational infrastructures are very weak and there is lack of equality of access of education for all groups. There is insufficient supporting material for teaching in many schools and a lack of respected teachers with training to enable them to let other voices be heard so that students can learn about different interpretations and truths. Indeed, Rahman (1982) argues that it is hard to find good scholars in Muslim countries because of the inadequate educational systems and their teaching methods, as well as government censorship and patronage. $\mathrm{He}$ argues that the problem goes beyond lack of infrastructure; in particular, he notes that teachers simply present statistical bodies of facts which are to be learnt strictly by memorisation, rather than encouraging creative learning, which requires intellectual and imaginative efforts (Rahman, 1982). He asserts that teachers in Islamic countries are not educated to embrace modern knowledge or to develop critical, analytical minds; meanwhile, they have maintained classical theological learning, and have consequently produced imams who are ill-informed about other cultures and 
forms of knowledge (Rahman, 1982). This can lead to resistance to the introduction of peace education, rather than constructive cooperation.

This is in line with Fandy's (2007: 93) argument that "the crisis of education in the Muslim world is not primarily one of infrastructure - a hardware problem - but lies in 'software': what is being taught, how it is being taught and the people who are teaching it". In this way, at present, teachers may lack skills required for presenting peace-orientated education. Moreover, because of lack of resources, providing up-to-date teacher training is difficult. Thus, when PEPs meet the specific challenges in Middle East education, they could be very useful in Islamic societies as a means to enabling critical appraisal of discourses that, up until now, have been taken for granted.

\section{WHAT NEEDS TO BE DONE}

As the above discussion indicates, there is a wide range of evidence within the existing literature that many current Middle East education systems aim to instil undisputed knowledge and, in doing so, discourage creative thought and critical thinking, which does not encourage students to assess whether information is valid and so makes them vulnerable to believing what they are told by any authoritative speaker, even if this involves incitement to hatred and violence. (For more in depth information, see Doumato and Starrett 2007). On the other hand, as Freire (1970) asserts, while education systems have the power to dehumanize and oppress populations, education can also be peacefully empowering, giving people the freedom to transform their lives. Peace education challenges those particular interpretations of religious scripts and acquired knowledge that can support domination and suppression of different viewpoints, making people vulnerable to extremist discourse. However, as Bjerstedt (1993:161-162) asserts, in conflict-affected areas "peace education faces difficulties ... because it faces an established culture which is basically bellicose".

In most post-conflict societies,, PEPs are new and consequently they lack relevant teaching experts and materials. Moreover, as Surya (2008) demonstrates, implementation of PEPs also faces difficulties linked to high running costs and tuition fees. Therefore, for the time being, they need help and support from outsiders such as INGOs. Indeed, without the support of the intergovernmental University of Peace, the MA degree course in Peace and Conflict Resolution at Duhok University; similarly, the establishment of the Department of Peace and Human Rights at the University of Dohuk would not have been possible without the support of the German NGO, Gesellschaft für Internationale Zusammenarbeit GmbH (GIZ), while the Higher Diploma of Peace would not have come into existence without the support from New York University. However, in some places, PEPs run by INGOs meet strong resistance as people suspect hidden, implicit aims that threatened their culture as they distrust anything from abroad (Harris, 1992). This reflects prevalent societal discourses in modern Muslim states that perceive peace education as a way to introduce Western ideas and indoctrinate students (Hicks, 1988:176; Ardizzone, 2002; Harris and 
Morrison, 2003:165); despite this, because PEPs are not identical in every country, these fears are being allayed by the success of some programmes.

Furthermore, in some cases, PEPs could further strengthen the inequality and injustices already in place. This argument is supported by Allport (1954) who asserts that equal status during the contact phase among participants in a conflicting situation is a precondition required for contact outcomes to be effective. For example, because of the large discrepancy between the Palestinians and Israelis in terms of equality, justice and prosperity, a possible and legitimate resolution will require the end of the oppression and injustices towards Palestinians, on the one hand, and a cessation of violent tactics by Palestinians to force change, on the other.

Therefore, some scholars believe that raising awareness through PEPs in Muslim countries might lead to further social conflict. For example, Parlevliet states:

Human rights education does not work in communities fraught with conflict unless it is part of a comprehensive approach. ... In fact, such education can be counterproductive and lead to greater conflict if people become aware of rights which are not realised. In this respect, human rights education can increase the potential for conflict (cited in Agarwal, 2014:37).

To ensure that peace-orientated interventions are constructive, it is important to follow three main guidelines. Firstly, peace education needs to be based on local perspectives combining local ownership with the international help, accepting that the latter has aided many post-conflict societies in implementing PEPs (Cole and
Barsalou, 2006). This approach has been taking place in other domains but integrating the peace education approach into formal education remains to be a reality. For example, many INGOs have taken the initiative of including the local perspectives in designing and implementing peacebuilding projects. To tackle the problem of lack of capacities of local agencies, INGOs provide help through trainings to build local capacities in peacebuilding, including how to initiate, design and implement peacebuilding activities. In general, such programs are supervised and followed up by both local and international NGOs staff. To enable INGOs to be more aware of fragile contexts and conflict sensitivities, they provide training of GECARR (good enough context analysis for rapid responses), MSTC (making sense of turbulent contexts), and IPACS (integrating peacebuilding and conflict sensitivities). These aim to avoid doing harm to the host society and also to provide better understanding of the context and recommendations for key stakeholders. The Center for Peace and Conflict Resolution Studies of the University of Dohuk is an example of this kind of initiative. The centre, which works in partnership with the New York University Center for Global Affairs, aims is to close the gap between the international and local understanding to provide better help to local people. It has set up joint research projects with international universities and INGOs and, also, liaises between the grassroots and middle level agencies to better articulate local needs to the INGOs. This involves organising group meetings with locals to articulate their needs and interests to INGOs who implement 
projects in their areas. This kind of liaison and partnership enables local peacemakers to avoid bias through taken-for-granted knowledge and leads to more mutual understanding between the Western and Middle East approaches (Mohammed, 2016).

Secondly, countering terrorism and violence needs to be by non-violent means. Therefore, education needs to introduce peaceful discourses to counter violent ones. People in Muslim majority states have lived with discourses of violence and hatred toward the 'other' for so long that they have become part of life. While passive acceptance of these is a problem and, as Zizek (2008:p183) argues, "sometimes, doing nothing is the most violent thing to do" (p. 183), Zizek also warns that the main threat does not lie in passivity but in the pseudoactivity that only validates things as they are.

Thirdly, and no less significantly, peace education also needs to take an inclusive approach that ensures all ethnic groups living in the society affected are represented fairly in the process of education. Muslim Arab states are multiethnic societies that have long histories of ethnic hatred, violation of minorities' rights and education can be a remedy to restore relationships and transform negative ethnic stereotypes (Roberts-Schweitzer, 2006:2).

Several INGOs have begun to take on board the issues discussed above when introducing PEPs; being consciously inclusive and making the local perspectives central to their approach. However, in most cases, such as those provided by Norway and Sweden, peace education is being introduced as a complete package to developing countries and these have been criticised as being addressed principally to secular states, thus marginalising the rights of religious states. Since people are different, with different cultures, religions and languages, the universality of rights is a challenging concept, especially in relation to state sovereignty and cultural relativism. However, globalization is rapidly increasing interconnections and interdependence; thus, multiculturalism within countries is a fact. Thus, PEPs are likely to be based on the most suitable set of principles that the majority agree to share with one another so, thus excluding minorities. To ensure that this is not the case, we need to counter the culturally-specific discourses that support violent conflict, discussed in the previous sections.

\section{COUNTERING VIOLENT DISCOURSES WITH PEACE-ORIENTATED DISCOURSES}

In order to overcome challenges facing building peace, peace education provides counter discourses and focuses on the search to understand the legitimatization of violence and the discourses that serve this. As Foucault (1978: 95-96) argued "when there is power there is resistance". Knowledge is based on hermeneutic tradition (interpretative understanding) and it is always situated in relation to interests (Habermas, 1972) and power (Foucault, 1980). Thus, to challenge predominant discourses of violence, it is important to understand the interests involved.

Giddens identified how talking and dealing with conflict and violence are intersected with the interests of dominant groups' ideology. $\mathrm{He}$ indicated three phases in which dominant 
discourse is reproduced - legitimation, preservation of the status quo, and simultaneously sustaining and denying social contradictions - and indicated how peace studies can challenge this: 1) legitimatisation needs to be countered by involving peaceful religious discourses so that peace education will become perceived as more legitimate; 2) peaceful religious discourses can challenge the status quo by exposing and correcting the implicit and overt assumptions among Muslim Arab states that peace education is inherently Western knowledge and supports awareness that it is not threatening the Islamic religion; 3) By exposing and challenging social contradictions, peace education can prevent social conflict escalating into violence (Giddens, 1997). Since, in peace education, conflict is seen as potentially beneficial, it can enable students to build the knowledge and skills required to make conflict constructive rather than accepting it as always destructive.

As mentioned above, religion can contribute to peace-making or to war-making and this is acknowledged in all major religions, including Islam, Christianity, and Judaism. There are numerous examples of violent discourse promulgated in the name of religion. In the name of Christianity, people carried out collective violence against Muslims during the Yugoslavian civil war (Johansen, 1997). Moreover, in such cases, it is the leaders that use and manipulate religion for their own purposes, mobilising and radicalising people. There are many examples of this: Younger people among Catholics and Protestants in Ireland became radicalized and so became involved in collective violence against each other. Buddhist monks spread hatred toward the minority Muslims in Burma by influencing their acolytes. The Crusades of 11th -13th centuries involved Christianity in direct wars with Muslims. In1947, groups of radical Jews promulgated apartheid violence against Palestinians (Ellens, 2007). Zionists continue to enact collective violence against Palestinians . In Sri Lanka and India, there are incidences of radical youths killing monks and monks killing other monks for political power (Johansen, 1997).

In contemporary times, notably in Iraq and Syria, radical Muslims have been violating and killing other ethnicities, as well as fighting among themselves with Shiia and Sunni killing one another. As a result, scholars are concerned about the problems of intolerance based on religion and the concerns that if nothing is done this may grow. In response to this, Appleby (2000) argues that a new form of conflict transformation - 'religious peacebuilding' - is taking shape on the ground, in and across local communities plagued by violence. While it is a promising development, he sees it as still "inchoate and fragile, uncoordinated and in need of greater numbers of adequately trained practitioners, more study and testing, and theoretical elaboration" (Appleby, 2000: 7). It is important to recognize "the interrelatedness of religious involvement in peacemaking at every phase of a conflict and at various levels of society" (Appleby, 2000: 211). Hence, the problem is growing and to overcome the anticipation that there will be a major religious war between the West and Islam, it is important to bring religion to the foreground. 
Many scholars have demonstrated religion's ability to encourage sustainable peace (Cynthia Sampson (1997); Appelby (2000) and Reychler (1977); Johnston and Sampson (1994)). Lederach (1995: 109-118) argues that to resolve the arguments of cultural and religious conflicts requires an understanding of one another beliefs and worldviews. Hence, religion has to be present in peacebuilding initiatives. In particular, in multiethnic societies, interreligious dialogue at all levels becomes especially important. If religion is given more opportunities in PEPs, it would be highly beneficial both in dispelling misunderstandings and in creating and promoting peaceful discourses.

\section{NEGOTIATING CULTURALLY DIFFERENT APPROACHES TO EDUCATION AND KNOWLEDGE}

Huntington (1996) argued that future world conflicts will not be primarily ideological or economic but cultural, a clash between civilisations with radically different worldviews. In the same vein, Jenkins (2007:13) anticipated worldview conflicts in the form of a "new age of Christian crusades and Muslim Jihads", "international religious-oriented alliances". And others have predicted that the wars in Middle East might be the beginning of the clash (Blaker et al., 2003:10-11). Recent forms of intervention in resolving conflicts in the Middle East have failed and the outcome has been the multiplication of the 'failed states' which create the conditions for the emerging of 'new wars', mainly internal and characterized by new actors and forms of violence (Kaldor, 1999).

This situation highlights a major underlying and persisting issue that is crucial to international peace education interventions in the Middle East; this is insufficient understanding and dialogue between Western and Muslim Arab states. While this is a highly sensitive and complex subject, it needs to be addressed to enable international agencies to cooperate more effectively with Middle East governments and NGOs to promote sustainable peace. In particular, while the West has a sense of ownership of knowledge, many in the Muslim Arab states, currently, feels marginalised, dispossessed of knowledge, and that their culture is under threat from the Western hegemony (for more information see Edward Said's book, Orientalism (1978)). The consequent imbalance and mutual lack of trust is a factor even in local-sensitive attempts to introduce PEPs since Western institutions' desire to promulgate their knowledge is seen as intrusive. In this epoch of modernity and technology, there is a tendency to perceive ownership of knowledge to be in the hands of Westerners. They distinguish themselves from other forms of cultural knowledge considering their knowledge to be evolving, dynamic and progressive while, on the other hand, in Arab Muslim countries, people believe knowledge resides within religion and tradition (For example, see Rahman 1982).

Contemporary Western knowledge is largely based on the assumption that human rationality can be used to understand other societies and the human race has evolved past the era of superstitions, myths and beliefs, since they are not 
based on rationality and lack scientific basis. This leads to an implicit arrogance that human production of knowledge of science and societies is better understood by the West, and so they know what is best for other societies. Therefore, Western knowledge has developed a taken for granted status that assumes universality and seeks to share the benefit of this with other societies. This tends to reinforce a sense of supremacy of Western concepts and frameworks as being best for other societies and being able to provide the means for all societies to better understand and regulate themselves through the universalisation of human rights and neglect of cultural relativism. At the same time, many educationalists in Arab Muslim countries tend to reject all knowledge coming from the West, deeming it a threat to wipe out Islamic values and behaviour in students (for example, see Said 1978). Paris (2002: 637) argues that the practical version of peacebuilding developed after the Cold War is an updated version of the colonial enterprise whereby Western civilisation has a duty to civilise the other dependent populations and territories, which has again led to more divisions and hatred.

For instance, recent Western interventions in Iraq and Afghanistan are examples of the assumption that people are willing to embrace democracy without resistance or questioning, despite the West's lack of knowledge about the Arab Islamic cultures. This lack of understanding and negative stereotypes of Arab Muslims is entrenched, as explained by Edward Said's work, in particular, Orientalism (1978). In this, he argues that Arabs are presented as passive, chaotic, violent, passive, and always in need of
Western intervention/help to become, if possible, modern and rational beings (Said, 1978). Hence, the need for a more bottom up approach is acknowledged by scholars such as Lederach (1997:94) arguing, "the greatest resources for mainlining peace is in the longterm involvement of the grassroots people and culture". To support this, it is also important to dispel the assumption that peace education is intrinsically Western, or at least associated specifically with Western ideas, despite the fact that scholars and activists from many other cultures have been highly influential and active in peace studies.

Similarly, peace education is also criticised as seeking to impose Western ideas on developing countries by embedding them within educational systems, (Schell-Faucon, 2001; Ardizzone, 2001; Seitz, 2004). This viewpoint arises because many PEPs have been introduced in ignorance of traditional methods of conflict resolution, such as the elder mediations, and tribal and religious leader methods. Moreover, the history of colonisation and imperialism by Western countries, has also led people to doubt the implicit goals of PEPs. In particular, following ' $9 / 11$ ', the US has put pressure on many of the Muslim Arab states to change their education systems on the grounds that they are teaching hatred and racism which promotes graduate recruitment to extremist organisations. Thus, the war of weapons is reflected in the war of ideas that Donald Rumsfeld asserted was prevalent in Islamic schools (Grundmann, 2005). This has been exacerbated by the fact that PEPs have been supported by the US as a condition of support for education in Arab states; consequently, they face severe resistance 
from Islamic majority states who interpret it as an attack on national security. This reflects the dilemma whereby the US sees itself as part of the remedy to end terrorism while the Muslim majority states perceive the US as a threat to Islam. In Muslim Arab states it is commonly perceived that the West is the enemy of Islam and that this is a root cause of the conflicts of interest (For example, see النبهاني (2002)). Several scholars have written on the subject of civilizations being based on different religions, citing this as a situation which forms the basis of conflicts between them (شادي, 2002:148). Some see the humanitarian work of INGOs as a long war against Islam (النبهاني, 2002:181; Amara, 2004). Others perceive double standards in focussing on Middle East education while not pressurising Israel to change its education curriculum. For instance, Bar-Tal's (1998:723) analysis of 124 Hebrew textbooks used in 1994 indicates that most Israeli education textbooks describe Arabs as the enemy and killers.

This last point highlights the double standards that alienates Middle East educationalists when foreign states and/or international institutions emphasise dissemination of peace education while continuing to support structural violence in all domains; for example, the interference in a nation's affairs and/or the exploitation of its national resources. Structural violence is perpetuated at many levels: intelligence services; the overwhelming budgets spent on the manufacture and subsequent sale of arms; and indoctrinating discourses. When students have access to a variety of forms of international news via the internet, this form of violence will undermine their acceptance of peace education initiatives if they see them as another function of Western ideology being imposed on their country. Furthermore, many governments reap benefits from conflict and, consequently, finding support for a PEP can be difficult since the affected governments fear losing these and the power they gain from it. Bar-Tal and Yigal (2009) emphasise the importance of government support as a precondition for effective peace education, thus, this may exacerbate resistance to PEPs in Muslim Arab states (Bar-Tal and Yigal, 2009).

On the other hand, peace education provides the means to challenge Western impositions by questioning and criticising dominant structures and institutionalised oppression, it also encourages and develops skills that can engage students in challenging undisputed political, scientific, economic, nationalistic and religious pedagogical values that create discourses of domination. Through this, it aims to transform society into one of "critical, informed citizenry that is prepared to work for the common good" (Ardizzone, 2002:23) - and so to create genuinely peaceful inclusion of different voices needed. Thus, we need to encourage mutual respect for the aspects of the two cultures that benefit peace, to develop a way for these to be combined constructively, for instance, the critical thinking of the West and the respect for community of Middle East culture.

\section{CONCLUSION}

As discussed above, challenges to PEPs differ in different socio-political cultural contexts. Not only do international interventions need to be 
more responsive to this but the processes and structures moulding education in Arab Middle East states need to be reformed to encourage more creative thinking that can question belief in fate and destiny as ultimate forces that should be accepted. This belief can make people acquiescent and is vulnerable to exploitation by many leaders to prevent the populous from interfering in their objectives and to justify failure. However, peace education can help people to imagine a better future, to release them from a traditionally held, passive outlook, which is a first step towards creating a more harmonious world.

To support this, the paper argued that peace education should be considered dynamic, progressive and transformative and there is no one size fits all. It needs to enable the growing generation to develop strategies for sustainable peace that are relevant to Middle East culture and genuinely reflect Islamic teachings. Therefore, societies need to develop different programmes to address different issues. For PEPs to be effective in Islamic Arab societies, the local stakeholders need to be involved at all stages of these kinds of programmes, and involvement from the international community needs to be sensitive to this. The main peace education challenges have to do with infrastructures of education systems, the process of designing and choosing the education curriculum, the lack of understanding and cooperation between international endeavour and local acceptance. Programs need to be contextoriented, with the local perspective being central to the whole process of designing and implementation; but also with awareness of the importance of international intervention and providing the tools to challenge this when it is an imposition rather than a cooperative effort.

The problems associated with education that is inherently war-orientated are growing in the Muslim Arab states as well as throughout the world, and this urgently needs to be reformed. Establishing peace discourses that counter violent behaviour and beliefs is the solution to overcoming hatred and discriminative discourses. If the next generation is to learn to deal constructively with conflict in an increasingly complex modern world, rather than resisting or distrusting peace education as an imposition from the West, Muslim Arab states in the Middle East need to focus on generating local knowledge regarding peace education that develops an Islamic understanding that is relevant to the contemporary multi-ethnic society. Within this debate, religion is a double-edged sword - it can be used to disseminate values of war but it can also be a mainstay in disseminating the values of peace. Having so much experience of conflict and access to significant peaceful Islamic discourse, these states needs to strive to provide leadership in understanding conflict transformation rather than being reluctant recipients of international interventions.

\section{REFERENCES}

- Aarts, P., \& Nonneman, G. (2005). Saudi Arabia in the Balance: Political Economy, Society, Foreign Affairs. New York: New York University Press.

- Abu-Nimer, M. (2001). Conflict Resolution, Culture, and Religion: Toward a Training Model of Interreligious Peacebuilding. Journal of Peace Research, 38, 6, 685-704. 
- Abu-Nimer, M. (2003). Nonviolence and Peacebuilding in Islam. Gainesville, FL: University Press of Florida.

- Abu-Nimer, M. (2000). Conflict Resolution, Culture and Religion: Toward a Training Model of Interreligious Peacebuilding. Journal of Peace Research, 38, 6, 685-704.

- Agarwal, A. (2014). Human Rights Awareness among the People of Agra City: A Comparative Study. Journal of Culture, Society and Development, 3, 31-42.

- Al-Barakat, A. A. \& Al-Karasneh, S. M. (2005). The contribution of school textbooks in the early grades of education in preparing young children to become effective citizens: teacher perspective. Journal of Early Childhood Research, 3, 2, 169-91.

- Al-Kubaisi, Y. (2012). A journey of learning: The curriculum in Iraqi schools and higher education. In Brunskell-Evans, $H$. and $M$. Moore (Eds.). Re-imagining research for reclaiming the academy in Iraq: Identities and participation in post-conflict enquiry (pp.53-63).

The Iraq Research Fellowship Programme. Rotterdam: Sense.

- Ali, M. (2013). The religions and Islam. Retrieved April 6, 2013 from www.alnabatieh.com

- Allport, G. W. (1954, 1975, 1979). The Nature of Prejudice. Reading, MA: Perseus.

- Apple, M. (1990). Ideology and Curriculum. 2nd edn. New York: Routledge.

- Appleby, R. S. (2000). The Ambivalence of the Sacred: Religion, Violence and Reconciliation. Lanham, MD: Rowman and Littlefield.

- Appleby, R. S. (2006). Building sustainable peace: the roles of local and transnational religious actors. Paper presented at the Conference on New Religious Pluralism in World Politics, Georgetown University, Washington, DC.

- Appleby, Scott R., (2000). The Ambivalence of the Sacred: Religion, Violence, and Reconciliation. Lanham: Rowman \& Littlefield Publishers.

- Ardizzone, L. (2002). Towards Global Understanding: The Transformative Role of Peace Education. Current Issues in Comparative Education (4)2, 16-25.

- Bandura, A. (1973). Social learning theory of aggression. In J. F. Knutson (Ed.). The control of aggression: Implications from basic research (pp. 201-250). Chicago: Aldine.

- Bar-On, D. and Adwan, S. (2006). The Psychology of Better Dialogue between Two Separate but Independent Narratives. In R. I. Rotberg (Ed.). Israeli and Palestinian narratives of conflict: History's double helix (pp. 205-224). Bloomington: Indiana University Press.

- Bar-Tal, D. (1998). The rocky road toward peace: Beliefs on conflict in Israeli textbooks. Journal of Peace Research, 35, 723-742.

- Bar-Tal, D. and Yigal, R. (2009). Condition for development of peace education in intractable conflict: Direct and Indirect Models. Review of Educational Research, 79, 2, 557-575.

- Bennett, M., (1993). Towards Ethnorelativism: A Developmental Model of Intercultural Sensitivity. In Michael Paige (Ed.) Education for the Intercultural Experience (pp. 20-72). Yarmouth, ME: Intercultural Press.

- Bennett, Milton, (1986).Towards Ethnorelativism: A Developmental Model of Intercultural Sensitivity. In Paige M. (Ed.) Cross-Cultural 
Orientation: New Conceptualizations and Applications (pp. 27-71). New York: University Press of America.

- Bickmore, K. (2008). Peace and conflict education. In Arthur J., Davies I. and Hahn C. (Eds.) The sage handbook of education for citizenship and democracy (pp. 438-454). Los Angeles: Sage.

- Bijlsma, S. (2009) 'Teaching history: Looking for unity in Rwanda`s classrooms'. In Opportunities for change. Education innovation and reform during and after conflict. ed. by Nicolai, S. Paris, France: UNESCO, 218-229.

- Bjerstedt, A. (1993). Peace education in schools around the world at the beginning of the 1990s. In Bjerstedt, A. (Ed.) Peace education: Global perspectives (pp. 146-169) . Stockholm, Sweden: Almqvist and Wiksell International.

- Blaker, K., Buckner, E. M., Kagin, E. F., Kirkhart, B. (2003). The Fundamentals of Extremism: The Christian Right in America. New Boston Books.

- Brislin, R., Dan L. \& Mary, E. B. (1983). Conceptualizations of Intercultural Behavior and Training. In Dan Landis and Richard Brislin, (Eds.) Handbook of Intercultural Training (pp. 1-36). Elmsford, NY: Pergamon.

- Bush K. D. \& Saltarelli D. (2000). The Two Faces of Education in Ethnic Conflict: Towards a peacebuilding education for children. UNICEF.

- Cederman, L-E., Wimmer, A. and Min, B. (2010). Why Do Ethnic Groups Rebel? New Data and Analysis. World Politics, 62, 1, 87-119.

- Cederman, L-E., Skrede Gleditsch, K. \& Buhaug, H. (2013). Inequality, Grievances and Civil War. New York: Cambridge University Press.
- Cole, E. (ed.) (2007) Teaching the Violent Past History Education and Reconciliation. Rowman and Littlefield Publishers Inc.

- Cole, E. and Barsalou, J. (2006) Unite or Divide? The Challenges of Teaching History in Societies Emerging from Violent Conflict. United State Institute of Peace (USIP) Special Report.

- Danesh, H. B. (2006). Towards an integrative theory of peace education. Journal of Peace Education, 3, 1, 55-78.

- Darling, D. (2004). Special Analysis: The 12/04 Bin Laden Tapes. Winds of Change. Retrieved November $\quad 11, \quad 2014, \quad$ from http://www.windsofchange.net/archives/006101. html

- Davies, L. (2004). Building a civic culture post-conflict. Review of Education, 2, 3, 229-244.

- Dewey, J. (1990) The School and Society. Chicago: University of Chicago Press.

- Doumato, E. A. \& Starrett, R. G. (Eds.) (2007). Teaching Islam: Textbooks and Religion in the Middle East. Boulder, Colo: Lynne Rienner.

- Eisen, R. (2011). The Peace and Violence of Judaism: From the Bible to Modern Zion. New York: Oxford University Press.

- Eisler, R., (2000). Tomorrow's Children. Westview, Boulder, Colo.: Westview Press.

- El-Baz, F. (2009). Reform in Arab Countries: the Role of Education. The Journal of Education, 188,3 .

- Ellens J. H. (Ed.) (2007). The Destructive Power of Religion: Violence in Judaism, Christianity and Islam. Westport, CT: Praeger Publishers.

- Fandy, M. (2007). Enriched Islam: the Muslim Crisis of Education. Survival, 49, 2. 
- Firer, R. (2002). The Gordian knot between peace education and war education. In Salomon, G. and Nevo, B. Peace Education: The Concept, Principles, and Practices Around the World. Hillsdale, NJ: Lawrence Erlbaum.

- Foucault, M. (1980). Power/Knowledge: Selected Interviews and Other Writings 1972-1977. London: Harvester Press.

- Foucault, M. (1978). The History of Sexuality Vol. I. (R. Hurley trans), New York: Pantheon.

- Fox, J. (1999). The Influence of Religious Legitimacy on Grievance Formation by EthnoReligious Minorities. Journal of Peace Research, 36, 3, 289-307.

- Freire, P. (1970). Pedagogy of the Oppressed. New York: The Continuum International Publishing Group, Inc.

- Galtung, J. (2009). Towards a Conflictology: A Quest for Trans-Disciplinarity. In Ennis Sandole, Sean Byrne, Ingrid Sandole-Staroste, and Jessica Senehi, (Eds.) Handbook of Conflict Analysis and Resolution (pp. 511-524). London: Routledge.

- Giddens, A. (1997). Sociology (3rd edn). Polity Press: Cambridge.

- Gopin, M. (2002). Holy War, Holy Peace: How Religion Can Bring Peace to the Middle East. Oxford: Oxford University Press.

- Gopin, M., (2000). Between Eden and Armageddon: the Future of World Religions, Violence, and Peacemaking. Oxford: Oxford University Press.

- Grundmann, J. (2005). Islamist Responses to Educational Reform. ISIM Review 15.

- Gudykunst, W. \& Hammer, M., (1983). Basic Training Design: Approaches to Intercultural Training. In Landis Dan \& Brislin, R., (Eds.)
Handbook of Intercultural Training (pp. 118155). Elmsford, NY: Pergamon

- Gutek, G. L. (2006). American Education in a Global Society: International and Comparative Perspectives. Long Grove, Illinois: Waveland Press, Inc.

- Habermas, J., (1972). Knowledge \& Human Interests. (J. Shapiro Trans.) Beacon Press.

- Hansenclever, A. \& Rittberger, V. (2000). Does Religion Make a Difference? Theoretical Approaches to the Impact of Faith on Political Conflict, Millennium. Journal of International Studies, 29, 3, 641-674.

- Harris, I. (1999). Types of peace education. In Raviv, A. Oppenheimer, L. and Bar-Tal, D. (Eds.) How Children Understand War and Peace (pp. 299-317). San Francisco: JosseyBass

- Harris, I. \& Morrison, M. (2003). Peace Education. (2nd Edn.). Jefferson, NC: McFarland and Co.

- Henderson, M., (1996). The Forgiveness Factor. In Hewstone, M. and Rupert B., (Eds.). Contact and Conflict in Intergroup Encounters. Oxford and New York: Basil Blackwell.

- Hicks, D. (1988). Understanding the Field in Education for Peace: Issues, Principles, and Practice in the Classroom. London: Routledge.

- Huntington, S. (1996). The Clash of Civilizations and the Remaking of World Order. New York: Simon and Schuster.

- Iain A., (2005). The Ethics of Peace and War. Edinburgh: Edinburgh University Press.

- Ignatieff, M. (2001). Human Rights as Politics and Idolatry. (The University Center for Human Values Series). Princeton: Princeton University Press. 
- Jabri, V. (1996). Discourses on Violence: Conflict Analysis Reconsidered. Manchester: Manchester University Press.

- Jenkins, P. (2007). God's Continent: Christianity, Islam, and Europe's Religious Crisis. Oxford: Oxford University Press.

- Johansen, R. (1997). Radical Islam and Nonviolence: A Case Study of Religious Empowerment and Constraint among Pashtuns. Journal of Peace Research 34, 1, 53-71.

- Kaldor M. (1999). New and Old Wars: Organized Violence in a Global Era. Cambridge: Polity Press.

- Ladson-Billings, G. (2005). The evolving role of critical race theory in educational scholarship. Race Ethnicity and Education, 8, 1, 115-119.

- Lederach, J. P. (1997). Building Peace: Sustainable Reconciliation in Divided Societies. Washington, D.C.: United States Institute of Peace.

- Lederach, J. P. (1999). The Journey toward Reconciliation. Scottdale, PA: Herald Press.

- Leirvik, O. (2004) Religion Education, Communal Identity and National Politics in the Muslims World. British Journal of Religious Education, 26, 3, 223-236.

- Lester, E. (2011). Teaching about Religious: A Democratic Approach for public schools. Ann Arbor: University of Michigan Press.

- Mandelbaum, M. (2002). The Ideas That Conquered the World: Peace, Democracy, and Free Markets in the Twenty-First Century. New York: Public Affairs.

- Matyok, T. (2011). Peace and conflict studies, reclaiming our roots and designing our way forward. In Tom Matyok, Jessica Seheni and
Sean Byrne (Eds.). Critical Issues in Peace and Conflict Studies: Theory, Practice and Pedagogy. Rowman and Littlefield (pp. $293-$ 309).

- McGlynn, C., Zembylas, M. \& Bekerman Z. (Eds.) (2013). Integrated Education in Conflicted Societies. Palgrave Macmillan.

- Mchoul, A. \& Grace, W. (1993). A Foucault Primer: Discourse, Power and the Subject. New York: New York University Press.

- Mohammed, A. M. (2016). Peace Education in Iraqi Kurdistan Schools: An Analysis of Human Rights and History Education Curriculum. $\mathrm{PhD}$ thesis. Coventry University, UK.

- Montville, J. (1991). Track Two Diplomacy: The Arrow and the Olive Branch: A case for Track Two Diplomacy. In, V. D. Volkan M.D., J. Montville, \& D. A. Julius (Eds.), The Psychodynamics of International Relations: Vol. 2. Unofficial diplomacy at work (pp.161175). Massachusetts: Lexington Books.

- Moore, D. L. (2007). Overcoming Religious Illiteracy: A Cultural Studies Approaches to the study of Religion in Secondary Education. New York: Palgrave MacMillan.

- Nieto, S. (2002). Language, Culture, and Teaching: Critical Perspectives for a New Century. Mahwah, NJ: Lawrence Erlbaum Associates.

- Paris, R. (2002). International peacebuilding and the 'mission civilisatrice'. Review of International Studies, 28, 637-656.

- Rahman, F. (1982). Islam and Modernity: Transformation of an intellectual tradition. Chicago, IL: University of Chicago Press.

- Ramirez-Barat, C. \& Duthie, R. (2015). Education and transitional justices. Opportunities and 
Challenges for Peacebuilding. International Center for Transitional Justice.

- Reardon, B. (1982). Militarization, Security, and Peace Education: A Guide for Concerned Citizens. Valley Forge, PA: United Ministries in Education.

- Roberts-Schweitzer E., (2006). Introduction. In Roberts- Schweitzer Eluned (Ed.). Promoting Social Cohesion through Education: Case Studies and Tools for Using Textbooks and Curricula. Washington, DC: The World Bank.

- Said, E. (1978). Orientalism. London: Penguin Books.

- Sameer, A. (2002). About Political Islam. The Way Magazine 5, 61.

- Sampson, C. (1997). Religion and Peacebuilding. In Zartman W. and Rasmussen L. (Eds.), Peacemaking in International Conflict: Methods and Techniques (pp.273-315). Washington DC: United States Institute of Peace.

- Sayigh, Y. (2010). Policing the People, Building the State: Authoritarian transformation in the West Bank and Gaza. Carnegie Papers, Beirut: Carnegie Endowment for International Peace.

- Seitz, K. (2004). Education and Conflict: The role of education in the creation, prevention and resolution of societal crises - consequences for development cooperation. GTZ (Deutsche Gesellschaft für Technische Zusammenarbeit).

- Sharef, H. A. (2nd-3rd of April 2007). The challenges faced changing the Islamic curriculum in the Islamic world. Islam and the Contemporary Challenges. Paper presented in the Conference of Islam and the Contemporary Challenges at the Islamic University in Saudi Arabia.
- Smoker, P. and Linda, G. (1996). Spirituality, Religion, Culture and Peace: Exploring the Foundations for Inner-Outer Peace in the Twenty-First Century. International Journal of Peace Studies, 1, 1, 57-114.

- Surya, N. P. (2008). Access to Peace Education. In.

Bajaj, M. (Ed.). Encyclopedia of Peace Education. Columbia: Teachers College, Columbia University.

- Tawil, S. \& Harley, A. (2004). Education and Identity-based Conflict: Assessing curriculum policy for social and civic reconstruction. In Tawil, S. and Harley, A. (Eds.) Education, conflict and social cohesion. Geneva: UNESCO.

- UNESCO (1995) Declaration and integrated framework of action and education for peace, human rights, and democracy. Paris: UNESCO.

- UNESCO (2011). Education for All, Global Monitoring Report. Paris: UNESCO.

- Valverde, G. A. (2005). Curriculum Policy seen through High-Stakes Examinations: Mathematics and Biology in a Selection of School-leaving Examinations from the Middle East and North Africa. Peabody Journal of Education, 80, 1, 29-55.

- Žižek, Slavoj (2008). Violence. London: Verso.

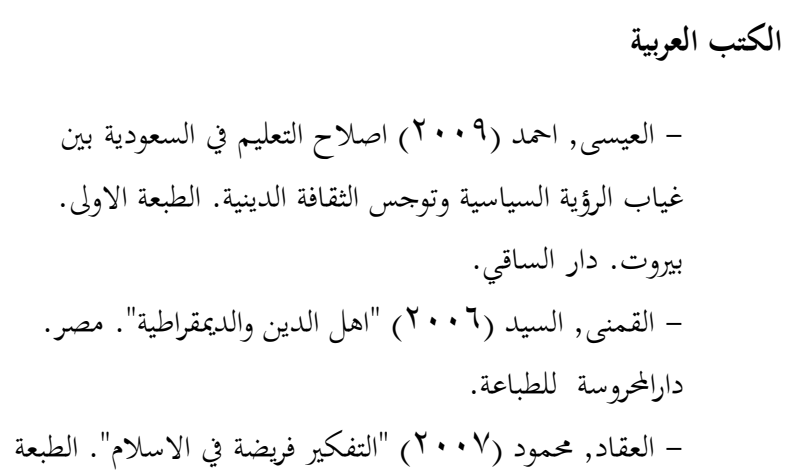




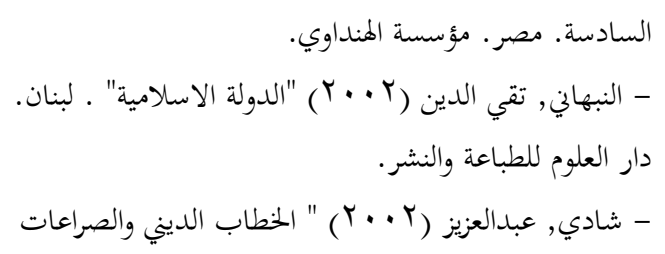

السادسة. مصر. مؤسسة الهنداوي.

دار العلوم للطباعة والنشر.

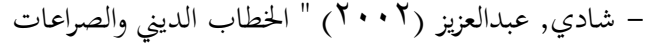

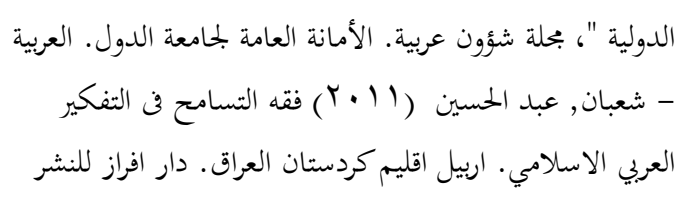

الدولية "، بحلة شؤون عربية. الأمانة العامة لجحامعة الدول. العربية

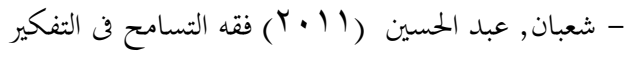

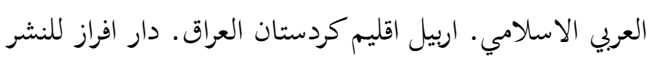

يوخته - ئه

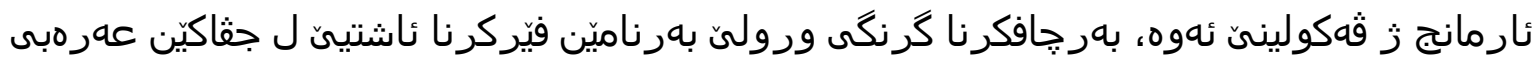

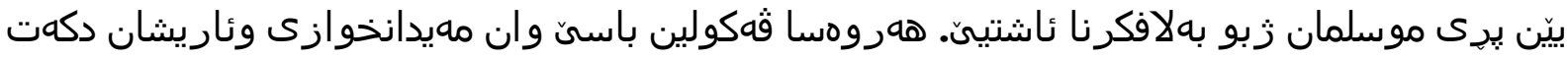

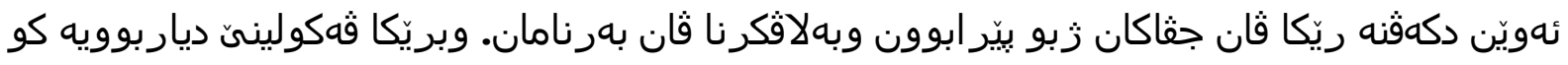

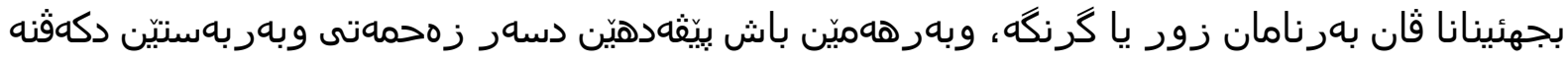

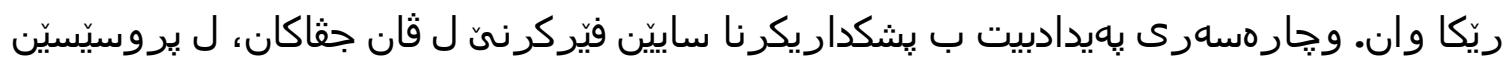

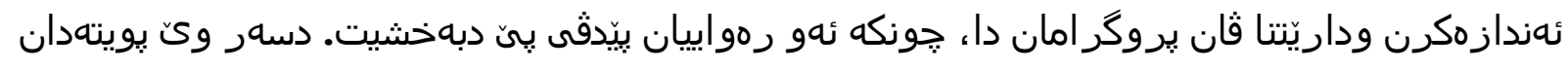

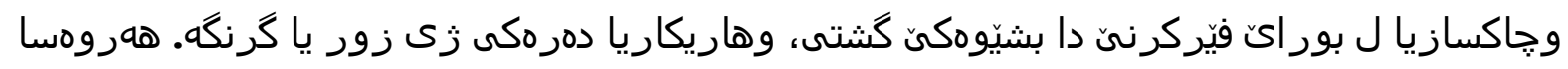

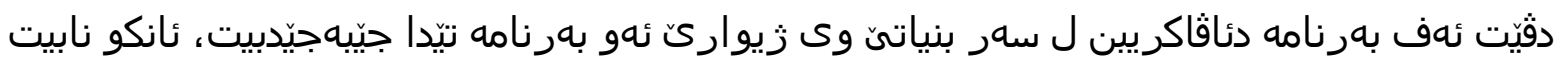

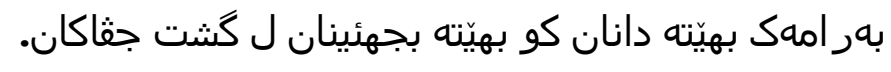

تحديات تطبيق برامج تعليم السلام في دول الشرق الاوسط العربيه

الخلاصة

يهدف البحث الى ابراز اهمية و دور برامج تعليم السلام في المجتمعات العربية الغالبية المسلمة لنشر النيا

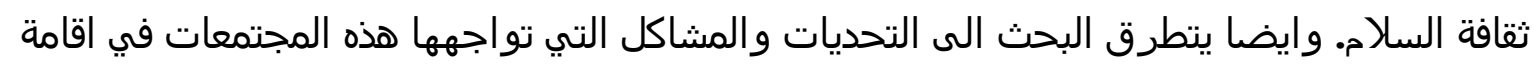

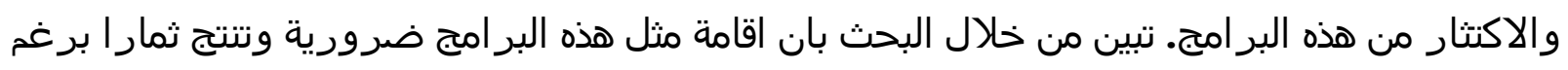

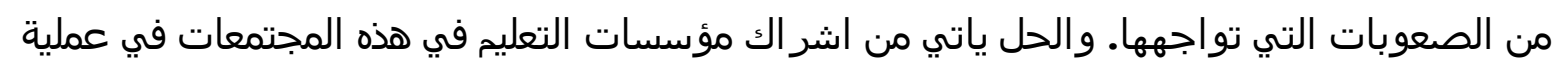

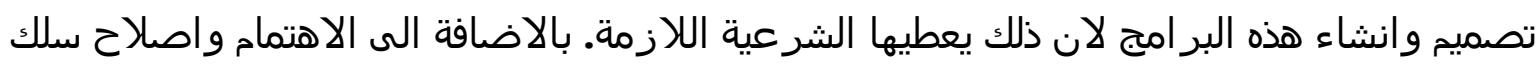

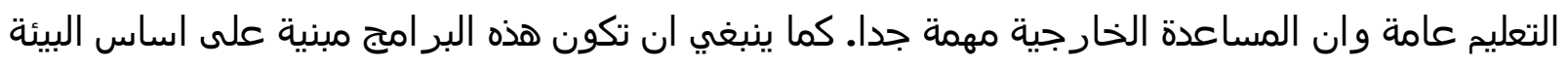
التي تعمل فيها هذه البرامج اي لا يصلح عمل برنامج واحد ويتم تظبيقه في جميع المجتمعات. 